\title{
ACTIVITY-GUIDED ISOLATION OF A NOVEL PROTEIN FROM FOENICULUM VULGARE WITH ANTIFUNGAL AND ANTIBACTERIAL ACTIVITIES
}

\author{
Hira Munir ${ }^{1}$, Muhammad Shahid ${ }^{2}$, Zinayyera Subhani ${ }^{2}$ and Raheela Jabeen ${ }^{3}$ \\ ${ }^{1}$ Department of Biochemistry and Biotechnology, University of Gujrat, Gujrat, Pakistan \\ ${ }^{2}$ Protein Molecular Biology Lab, Department of Biochemistry, University of Agriculture, Faisalabad-38040, Pakistan \\ ${ }^{3}$ Department of Biochemistry and Biotechnology, The Women University, Multan, Pakistan
}

This is an open access article distributed under the Creative Commons Attribution License, which permits unrestricted use, distribution, and reproduction in any medium, provided the original work is properly cited

\section{ARTICLE DETAILS ABSTRACT}

\section{Article History:}

Received 12 November 2017 Accepted 12 December 2017 Available online 1 January 2018
This study describes the activity-guided isolation and purification of antimicrobial proteins from the seeds of Foeniculum vulgare. Purification was carried out by $\left(\mathrm{NH}_{4}\right)_{2} \mathrm{SO}_{4}$ precipitation, gel filtration and ion-exchange chromatography. Antifungal and antibacterial activities were determined by disc diffusion assay method. SDSpolyacrylamide gel electrophoresis revealed that the purified protein was a monomer with molecular mass of $60 \mathrm{kDa}$. This is a first report on purification of a protein from Foeniculum vulgare, which possesses a strong and broad spectrum antimicrobial activity. Our results suggest that the antimicrobial properties of this plant seed may be further investigated to explore the possibility of using them in the treatment of candidal or bacterial infections.

\section{KEYWORDS}

Foeniculum vulgare, gel filtration, antifungal, antibacterial, electrophoresis

\section{INTRODUCTION}

Fennel is an annual, biennial or perennial plant, depending on the variety, belonging to Apiaceae family and is native to the Mediterranean area [1]. It has been cultivated and introduced into many regions outside that zone; it is grown commercially in some of them, such as Russia, India, China and Japan [2]. Mature fennel fruit and essential oil are used as flavoring agents in food products such as liqueurs, bread, pickles, pastries, and cheese. They are also used as a constituent in cosmetic and pharmaceutical products [3]. Extracts from fennel plant has been used as an antispasmodic, diuretic, analgesic and antipyretic and has antimicrobial properties; it can also be used for skin disorders, conjunctivitis and blepharitis of the eye [4].

Herbs and spices are amongst the most important targets to search for natural antimicrobials from the point of view of safety [5]. They may provide an alternative to currently used pest control agent [6]. In East Asia, work has been done with plant extracts and essential oils to control stored food mites [7].

Foeniculum vulgare, vernacular name; Saunf (Urdu), Fennel (English) is an aromatic plant. The essential oils, compounds and their antimicrobial, insecticidal as well as repellent activities of this medicinal plant have been reported [8]. They have the potential of being acute ovicidal, fumigant, insect growth regulatory and insecticidal against various insect species [9].

Despite the enormous number of studies conducted on the antimicrobial properties of aromatic plants, very little work has been published on the antimicrobial properties of Foeniculum vulgare (fennel). It is hoped that the present report will contribute to the existing state of knowledge about the antimicrobial properties of medicinal plants.

\section{MATERIALS AND METHODS}

Seeds of Foeniculum vulgare (Voucher No. 11365, 26-05-1929,), Herbarium Punjab Agriculture College, Lyallpur, Shelf No. 6/35) were obtained and taxonomically identified from the Department of Botany, University of Agriculture, Faisalabad.

\subsection{Extraction}

Seeds were made dirt free. Seeds were extracted in potassium phosphate buffer (pH: 7.0) following the method [10]. The plant seeds were mixed with extraction buffer, by a ratio of 1:2 i.e., $100 \mathrm{~g}$ of sample was mixed with 200 $\mathrm{mL}$ of extraction buffer. Then this mixture was ground at $4^{\circ} \mathrm{C}$. The next step was to centrifuge the mixtures at $10,000 \mathrm{xg}$ at $4{ }^{\circ} \mathrm{C}$ for 15 minutes. The residues were discarded, and the supernatant was separated and filtered to remove particles. The resultant filtrate (crude extract) was stored at $4^{\circ} \mathrm{C}$ till further analysis [11]. Protein contents at each step were determined by a researcher [12].

\subsection{Purification}

The proteins in the crude extract were precipitated with $\left(\mathrm{NH}_{4}\right)_{2} \mathrm{So}_{4}$ at $80 \%$ saturation by using a method given by some researchers [13]. The precipitated crude extract was centrifuged at $10,000 \mathrm{xg}, 4^{\circ} \mathrm{C}$ for 15 minutes. The residue was re-suspended in the extraction buffer. The residue and supernatants were tested for antimicrobial activities.

\subsection{Dialysis of the sample}

The re-suspended residues were dialyzed against distilled water to remove ammonium sulphate. The dialyzed samples were stored at $4^{\circ} \mathrm{C}$ in $100 \mathrm{~mL}$ sterilized bottles till further analysis [14].

\subsection{Gel filtration and anion exchange chromatography}

The dialyzed sample of Foeniculum vulgare was further purified by gel filtration, using Sephadex G-100 [13]. Absorbance of the eluents was recorded at $280 \mathrm{~nm}$ and $595 \mathrm{~nm}$. The fractions with maximum protein contents were pooled out and tested for antimicrobial activities. The fraction showing high activity was further purified by ion-exchange chromatography on DEAE-Sephadex A-50 column. The elutions were carried out in a gradient of sodium chloride of different molarity ranging from 0.2-1 M [15]. Molecular mass of the crude protein was determined by SDS-PAGE [16]. 


\subsection{Antimicrobial activities}

\subsubsection{Microbial strains}

The fennel seed extracts were tested against a panel of microorganisms, including four bacteria, Escherichia coli B10, Bacillus subtilis JS2004, Pasturella multocida local isolate, Staphylococcus aureus API Staph tac 6736152 and four pathogenic fungi, Aspergillus niger, Rhizopus solani, Alterneria alterneria and Aspergillus flavus. The pure bacterial and fungal strains were obtained from the Institute of Microbiology, University of Agriculture, Faisalabad, Pakistan. Bacterial strains were cultured overnight at $37^{\circ} \mathrm{C}$ using nutrient agar (Oxoid, Hampshire, UK) while fungal strains were cultured overnight at $27{ }^{\circ} \mathrm{C}$ on sabouraud dextrose agar (Oxoid, Hampshire, UK).

\subsubsection{Disc diffusion method}

The antimicrobial activity of the fennel seed extracts from different steps was determined by the disc diffusion method. Fungal spores and bacterial cultures were inoculated in Petri plates containing the respective medium and incubated at $27^{\circ} \mathrm{C}$ and $37{ }^{\circ} \mathrm{C}$ for fungi and bacteria, for 24 and $48 \mathrm{~h}$, respectively. Wicks paper discs $6 \mathrm{~mm}$ in diameter were then laid flat on the medium having fungal or bacterial growth and $100 \mu \mathrm{L}$ of the sample was applied on each disc. The Petri plates were incubated for $48 \mathrm{~h}$, for the growth of microbes. The antimicrobial activity was shown by the appearance of the clear zones around the growth.

The zones of inhibition were measured in millimeters with a zone reader [17]. Ciprofloxacin (Bacteria) and Terbinafine-HCl (Fungi) were used as standard. Disc without samples having autoclaved water was used as negative control. Minimum Inhibitory Concentrations (MIC) of crude extracts was performed using microtiter plate-based assay. For bacterial strains and for fungal strains a Florentine method was used given by a group researchers $[18,19]$.

\subsection{Statistical Analysis}

All the experiments were conducted in triplicate unless stated otherwise and statistical analysis of the data was performed by analysis of variance (ANOVA), using STATISTICA 5.5 (Stat Soft Inc, Tulsa, Oklahoma, USA) software. A probability value of $p \leq 0.05$ was considered to denote a statistically significance difference. All data are presented as mean values \pm standard deviation $(\mathrm{SD})$.

\section{RESULTS AND DISCUSSIONS}

Antimicrobial activity of the extracts of Foeniculum vulgare were tested against fungal (Aspergillus niger, Rhizopus solani, Alterneria alterneria and Aspergillus flavus) and bacterial strains (Escherichia coli, Bacillus subtilis, Pasturella multocida and Staphylococcus aureus) with strong inhibitory effect (Table 1); hence activity guided fractionation was carried out to isolate the respective protein. After performing antimicrobial assay, MIC of seed extracts of fennel was performed. The result is represented in table 2.

Table 1: The antimicrobial activity of the different samples collected at different steps of purification of Foeniculum vulgare

\begin{tabular}{|c|c|c|c|c|c|c|c|c|}
\hline $\begin{array}{c}\text { Tested } \\
\text { organi } \\
\text { sms }\end{array}$ & $\begin{array}{c}\text { Cru } \\
\text { de } \\
\text { Extr } \\
\text { act }\end{array}$ & $\begin{array}{c}\text { Supern } \\
\text { atant } \\
\text { after } \\
\left(\mathrm{NH}_{4}\right)_{2} \mathrm{~S} \\
\mathrm{O}_{4} \mathrm{ppt}\end{array}$ & $\begin{array}{c}\text { Resid } \\
\text { ue } \\
\text { after } \\
\left(\mathrm{NH}_{4}\right) \\
{ }_{2} \mathrm{SO}_{4} \\
\text { ppt }\end{array}$ & $\begin{array}{c}\text { Pe } \\
\text { ak } \\
\text { I }\end{array}$ & $\begin{array}{l}\text { Pe } \\
\text { ak } \\
\text { II }\end{array}$ & $\begin{array}{l}\mathrm{Pe} \\
\text { ak } \\
\text { III }\end{array}$ & $\begin{array}{l}\mathrm{Pe} \\
\text { ak } \\
\mathrm{IV}\end{array}$ & $\begin{array}{c}\text { Stand } \\
\text { ard }\end{array}$ \\
\hline \multicolumn{9}{|c|}{ Diameter of Inhibition Zone $(\mathrm{mm})$ including disc diameter of $6 \mathrm{~mm}$} \\
\hline $\begin{array}{c}\text { Pastur } \\
\text { ella } \\
\text { multoc } \\
\text { ida }\end{array}$ & $\begin{array}{c}14 \pm \\
1\end{array}$ & $13 \pm 1$ & $14 \pm 1$ & $\begin{array}{l}14 \\
\pm 1\end{array}$ & $\begin{array}{l}14 \\
\pm 1\end{array}$ & $\begin{array}{l}16 \\
\pm 1\end{array}$ & $\begin{array}{l}16 \\
\pm 1\end{array}$ & $22 \pm 1$ \\
\hline $\begin{array}{c}\text { Escheri } \\
\text { chia } \\
\text { coli }\end{array}$ & $\begin{array}{c}14 \pm \\
1\end{array}$ & $12 \pm 1$ & $14 \pm 1$ & $\begin{array}{l}16 \\
\pm 1\end{array}$ & $\begin{array}{l}14 \\
\pm 1\end{array}$ & $\begin{array}{l}16 \\
\pm 1\end{array}$ & $\begin{array}{l}16 \\
\pm 1\end{array}$ & $22 \pm 1$ \\
\hline $\begin{array}{c}\text { Bacillu } \\
s \\
\text { subtilis }\end{array}$ & $\begin{array}{l}20 \\
\pm 1\end{array}$ & $14 \pm 1$ & $16 \pm 1$ & $\begin{array}{l}14 \\
\pm 1\end{array}$ & $\begin{array}{l}14 \\
\pm 1\end{array}$ & $\begin{array}{l}14 \\
\pm 1\end{array}$ & $\begin{array}{l}16 \\
\pm 1\end{array}$ & $22 \pm 1$ \\
\hline $\begin{array}{c}\text { Staphy } \\
\text { locc- } \\
\text { ocus } \\
\text { aureus }\end{array}$ & $\begin{array}{c}12 \pm \\
1\end{array}$ & $14 \pm 1$ & $16 \pm 1$ & $\begin{array}{l}12 \\
\pm 1\end{array}$ & $\begin{array}{l}14 \\
\pm 1\end{array}$ & $\begin{array}{l}14 \\
\pm 1\end{array}$ & $\begin{array}{l}14 \\
\pm 1\end{array}$ & $22 \pm 1$ \\
\hline
\end{tabular}

\begin{tabular}{|c|c|c|c|c|c|c|c|c|}
\hline $\begin{array}{c}\text { Asperg } \\
\text { illus } \\
\text { niger }\end{array}$ & $\begin{array}{c}12 \pm \\
1\end{array}$ & $12 \pm 1$ & $14 \pm 1$ & $\begin{array}{l}12 \\
\pm 1\end{array}$ & $\begin{array}{l}12 \\
\pm 1\end{array}$ & $\begin{array}{l}14 \\
\pm 1\end{array}$ & $\begin{array}{l}14 \\
\pm 1\end{array}$ & $22 \pm 1$ \\
\hline $\begin{array}{c}\text { Altern } \\
\text { aria } \\
\text { altern } \\
\text { aria }\end{array}$ & $\begin{array}{c}13 \pm \\
1\end{array}$ & $13 \pm 1$ & $14 \pm 1$ & $\begin{array}{l}12 \\
\pm 1\end{array}$ & $\begin{array}{l}13 \\
\pm 1\end{array}$ & $\begin{array}{l}14 \\
\pm 1\end{array}$ & $\begin{array}{l}14 \\
\pm 1\end{array}$ & $22 \pm 1$ \\
\hline $\begin{array}{c}\text { Asperg } \\
\text { illus } \\
\text { flavus }\end{array}$ & $\begin{array}{c}22 \pm \\
1\end{array}$ & $16 \pm 1$ & $18 \pm 1$ & $\begin{array}{l}16 \\
\pm 1\end{array}$ & $\begin{array}{l}16 \\
\pm 1\end{array}$ & $\begin{array}{l}16 \\
\pm 1\end{array}$ & $\begin{array}{l}18 \\
\pm 1\end{array}$ & $22 \pm 1$ \\
\hline $\begin{array}{c}\text { Rhizop } \\
\text { us } \\
\text { solani }\end{array}$ & $\begin{array}{c}14 \pm \\
1\end{array}$ & $14 \pm 1$ & $16 \pm 1$ & $\begin{array}{l}12 \\
\pm 1\end{array}$ & $\begin{array}{l}12 \\
\pm 1\end{array}$ & $\begin{array}{l}12 \\
\pm 1\end{array}$ & $\begin{array}{l}14 \\
\pm 1\end{array}$ & $22 \pm 1$ \\
\hline
\end{tabular}

No activity was recorded in negative control disc. As the experiment was conducted in triplicate and means are given in the table. For purification, crude extract of $F$. vulgare seeds was subjected to ammonium sulphate precipitation to $80 \%$ saturation level. Strong antifungal and antibacterial activities were observed for the residue, showing that the activity was most likely due to some proteins and peptides.

Table 2: Minimum inhibitory concentration $(\mathrm{mg} / \mathrm{mL})$ of Foeniculum vulgare against fungal and bacterial species.

\begin{tabular}{|l|c|c|}
\hline Microorganisms & $\begin{array}{l}\text { Seed Extract } \\
\text { (mg/mL) }\end{array}$ & $\begin{array}{l}\text { Positive Control } \\
\text { (mg/mL) }\end{array}$ \\
\hline Bacterial Species: & & \\
\hline Pasturella multocida & $5.79 \pm 0.05$ & $23.43 \pm 0.02$ \\
\hline Escherichia coli & $5.78 \pm 0.05$ & $11.71 \pm 0.01$ \\
\hline Bacillus subtilis & $1.45 \pm 0.01$ & $93.75 \pm 0.09$ \\
\hline Staphyloccocus aureus & $1.75 \pm 0.07$ & $46.87 \pm 0.04$ \\
\hline Fungal species: & & $1.46 \pm 0.01$ \\
\hline Aspergillus niger & $0.36 \pm 0.03$ & $22.45 \pm 0.22$ \\
\hline Alternaria alternaria & $0.46 \pm 0.03$ & $93.75 \pm 0.09$ \\
\hline Aspergillus flavus & $0.78 \pm 0.02$ & $11.71 \pm 0.01$ \\
\hline Rhizopus solani & $1.449 \pm 0.01$ & \\
\hline
\end{tabular}

The residue, re-suspended in buffer after ammonium sulpahte precipitation, was applied to gel filtration column (Sephadex-G 100). One milliliter fractions were collected, and the absorbance was noted at 280 $\mathrm{nm}$ and $595 \mathrm{~nm}$ using Bradford reagent (Figure 1).

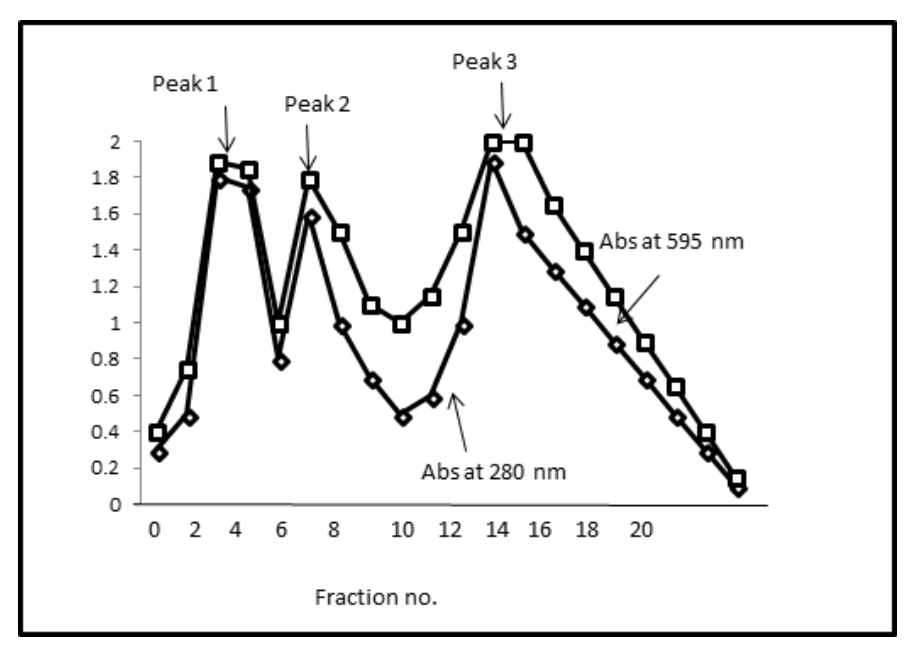

Figure 1: Gel filtration pattern of ammonium sulphate residues of Foeniculum vulgare.

Activity-directed antimicrobial effect revealed that no or little effect could be observed for the peak 1 (fraction 3 and 4), peak 2 (fraction 6), while peak 3 (fraction 13) exhibited strong effect against Pasturella multocida, Escherichia coli and Aspergillus flavus. It was concluded that fraction 13 had maximium effect. The proteins obtained from the fraction 13 of the gel filtration column were subjected to DEAE Sephadex chromatography (Figure 2). Gradient molar solutions of $\mathrm{NaCl}(0.2-1 \mathrm{M})$ were used for elution of sample. 


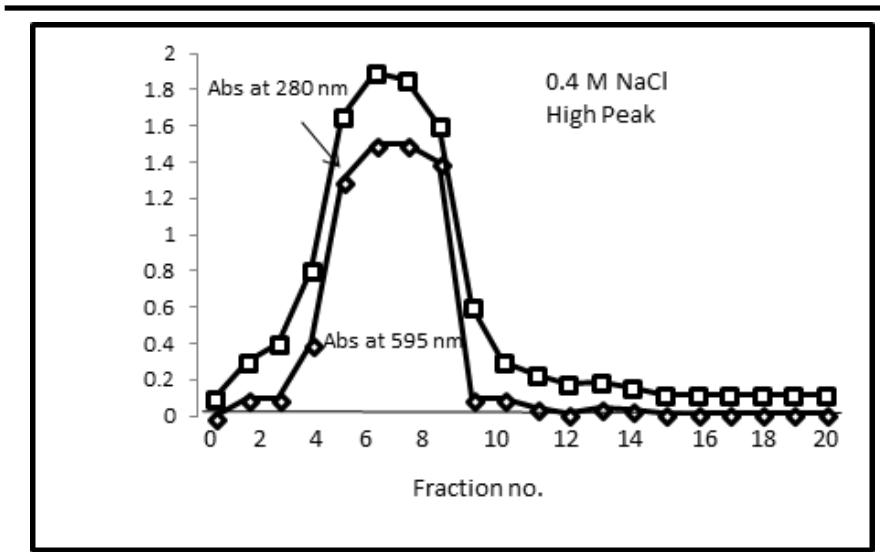

Figure 2: Ion exchange separation pattern of the $13^{\text {th }}$ fraction from gel filtration of Foeniculum vulgare.

A major peak was detected constituting fractions 5-8 with $\mathrm{NaCl}$ concentration of $0.4 \mathrm{M}$. The crude extract, fraction 13 of gel filtration and fraction 5 of the ion-exchange chromatographic sample were electrophoresed on SDS-polyacrylamide gel. It was observed that the antimicrobial protein migrated as a single coomassie stain band for the ion-exchange sample.

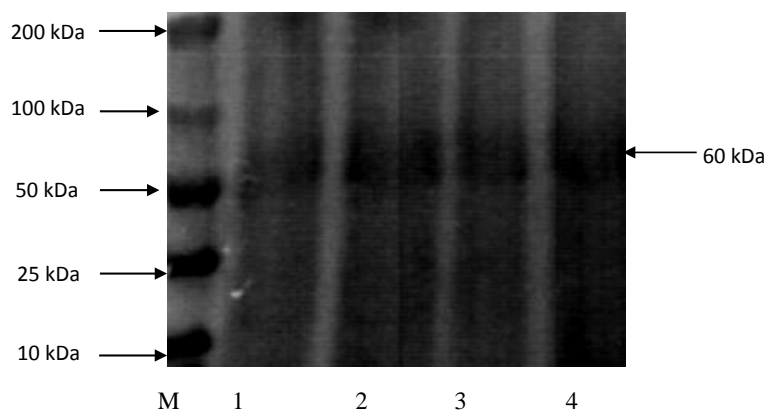

Figure 3: SDS-PAGE of seeds extracts at different stages of purification of Foeniculum vulgare. Lane M molecular mass markers. Lane 1 and 2 crude extracts, lane 3 is gel filtration extract and lane 4 is for ionexchange chromatographic fraction.

The estimated molecular mass of the protein was $60 \mathrm{kDa}$. SDS-PAGE of the crude extract showed many bands that disappeared after gel filtration, and finally a single protein band corresponding to $60 \mathrm{kDa}$ was obtained after ion-exchange chromatography. No report to our knowledge exists in the literature for purification of Foeniculum vulgare. However, antimicrobial proteins have been isolated by some researchers. A group researchers reported that the Gram-negative strains of bacteria, especially E. coli, have less sensitivity to fennel extracts [20]. In other study, they found that fennel exhibit an inhibitory effect against a wide range of Bacillius species [21]. There also reported that the extracts of fennel are active against Aspergillus species [22].

\section{CONCLUSION}

The results of this study show that Foeniculum vulgare is a good source of antimicrobial proteins. A $60 \mathrm{kDa}$ protein was purified from the plant that exhibited strong and broad spectrum antimicrobial activity. However, further studies like sequence analysis and characterization of the purified protein are necessary before its use as antimicrobial against pathogenic fungi and bacteria. Due to antimicrobial activity, seed extracts of $F$. vulgare can be used as supplement in pharmaceutical industries. These extracts are valuable not only for increasing shelf life of foodstuffs, but it could be a future target for replacing synthetic antibacterial agents.

\section{ACKNOWLEDGMENT}

Authors highly acknowledged the financial assistance of Higher Education Commission (HEC) Islamabad, Government of Pakistan for providing the project of under the program of Presidential Innovator award (PYI).

\section{REFERENCES}

[1] Barros, L., Carvalho, A.M., Ferreira, I.C.F.R. 2010. The nutritional composition of fennel (Foeniculum vulgare): shoots, leaves, stems and inflorescences. Food Science and Technology, 43, 814-818.

[2] Damjanovic, B., Lepojevic, Z., Zivkovic, V., Tolic, A. 2005. Extraction of fennel (Foeniculum vulgare Mill.) seeds with supercritical $\mathrm{CO}_{2}$ : comparison with hydrodistillation. Food Chemistry, 92, 143-149.
[3] Telci, I., Demirtas, I., Sahin, A. 2009. Variation in plant properties and essential oil composition of sweet fennel (Foeniculum vulgare Mill.) fruits during stages of maturity. Industrial Crops and Products, 30, 126-130.

[4] Ozbek, H., Ugras, S., Dulger, H. 2003. Hepatoprotective effect of Foeniculum vulgare essential oil. Fitoterapia, 74, 317-319.

[5] Singh, G., Maurya, S., Lampasona, M.P., Catalan, C. 2006. Chemical constituents, antifungal and antioxidative potential of Foeniculum vulgare volatile oil and its acetone extract. Food Control, 17, 745-752.

[6] Prajapati, V., Tripathi, A.K., Aggarwal, K.K., Khanuja, S.P.S. 2005. Insecticial, repellent and oviposition-deterrent activity of selected essential oils against Anopheles stephensi, Aedes aegypti and Culex quinquefasciatus. Bioresource Technology, 96, 1749-1757.

[7] Lee, C.H., Sung, B.K., Lee, H.S. 2006. Acaricidal activity of fennel seed oils and their main components against Tyrophagus putrescentiae, a stored-food mite. Journal of Stored Products Research, 42, 8-14.

[8] Han, M.K., Kim, S.I., Ahn, Y.J. 2006. Insecticidal and antifeedant activities of medicinal plant extracts against Attagenus unicolor japonicas. Journal of Stored Products Research, 42, 15-22.

[9] De Mendonca, K. F., Silva, S., Santos, K.K., Junior, K.L.A.R., Ana, A.E.G.S 2005. Activities of some Brazilian plants against larvae of the mosquito. Fitoterapia, 76, 629-636.

[10] Charles, A.L., Huang, T.C., Lai, P.Y., Chen, C.C., Lee, P.P., Chang, Y.H 2007. Study of wheat of flour-cassava starch composite mix and the function of cassava mucilage in Chinese noodles. Food Hydrocolloid, 21, 368-378.

[11] Szentmihályi, K., Vinkler, P., Lakatos, B., Illés, V., M. 2002. Then, Rose hip (Rosa canina L.) oil obtained from waste hip seeds by different extraction methods. Bioresource Technology, 82, 195-201.

[12] Bradford, M.M. 1976. A rapid and sensitive method for the quantification on microgram quantities of protein utilizing the principle of protein-dye binding. Annual Review of Biochemistry, 72, 248-254.

[13] Markus, R.W., Fernandis, A.Z. 2007. A manual for Biochemistry protocols. Manuals in Biomedical Research, 3, 17-21.

[14] Huynh, Q.K., Borgmeyer, J.R., Smith, C.E., Bell, L.D., Shah, D.M. 2001. Isolation and characterization of a $30 \mathrm{kDa}$ protein with antifungal activity from leaves of Engelmannia pinnatifida. Journal of Biological Chemistry, 316, 723-727.

[15] Shahid, M., Tayyab, M., Naz, F., Jamil, A., Ashraf, M., Gilani, A.H. 2008. Activity-guided isolation of a novel protein from Croton tiglium with antifungal and antibacterial activities. Phytotherapy Research, 22, 16461649.

[16] Laemmli, U.K. 1970. Cleavage of structural proteins during the assembly of the head of bacteriophage T4. Nature, 227, 680-685.

[17] Gulfraz, M., Mehmood, S., Minhas, N., Jabeen, N., Kausar, R., Jabeen, K., Arshad, G. 2008. Composition and antimicrobial properties of essential oil of Foeniculum vulgare. African Journal of Biotechnology, 7, 4364-4368.

[18] Sarkar, S.D., Nahar, L., Yashodharan, K. 2007. Microtitre plate-based antibacterial assay incorporating resazurin as an indicator of cell growth, and its application in the in vitro antibacterial screening of phytochemicals. Science Direct Methods, 42, 321-324.

[19] Kaiserer, L., Christoph, O., Renate, W.B., Wolfgang, B., Eva, L., Florentine, M. 2003. Characterization of the Penicillium chrysogenumantifungal protein PAF. Archives of Microbiology, 180, 204210.

[20] Anwar, F., Ali, M., Hussain, A.I., Shahid, M. 2008. Antioxidant and antimicrobial activities of essential oil and extracts of fennel (Foeniculum vulgare Mill.) seeds from Pakistan. Flavour and Fragrance Journal, 24, 170-176.

[21] Ozcan, M.M., Sagdic, O., Ozkan, G. 2006. Inhibitory Effects of Spice Essential Oils on the Growth of Bacillus Species. Journal of Medicinal Food, 9, 418-421

[22] Mimica-Dukic, N., Kujundzic, S., Sokovic, M., Couladis, M. 2003. Essential oil composition and antifungal activity of Foeniculum vulgare Mill obtained by different distillation conditions. Phytotherapy Research, 17, 368-371. 